\title{
INVESTIGACIÓN/RESEARCH
}

Recibido: 07/11/2014---Aceptado: 05/11/2014---Publicado: 15/12/2014

\section{NEOIstanbuLIBERAL: A CITY OF CAPITAL OR A CITY OF CULTURE?}

\section{Kaan Tasbasi: Yeditepe University, Turkey \\ ktasbasi@yeditepe.edu.tr}

\section{ABSTRACT}

This study aims to investigate how Istanbul is articulated to neoliberal globalisation through cultural events. Of special significance is the emphasis to be placed on this fact recurring once again, as it is in several cities in the U.S. and Europe, in a diversified context in İstanbul. While urban culture is determined as the major marketing instrument to make the city a point of attraction, urban place is commodified via urban culture marketing. One of the arguments of this study is that there exists a direct nexus between Istanbul becoming another global station of capital flows, and that the middle-class choosing this city as "a city to live". Given that one of the criteria for a city to be "a city to live" for the middle-class is the cultural life in the city, mega cultural events in Istanbul are essential. This phenomenon is fed by a couple of concepts (or rhetoric) such as "creative cities", "creative classes", "creative industries" and is being propagated through the media.

In this context, recent international cultural events organised in İstanbul are going to be evaluated in the study. The data set consists of "official information" provided by the organisers of these events and how they are represented in the media. Findings which are going to be intersected on an interdisciplinary hub of urban sociology/cultural sociology/communication studies, are going to be ascertained from a critical point of view.

1 PhD, Asst. Prof., Yeditepe University, Department of Radio TV and Cinema. 


\section{KEYWORDS}

Urban culture, creative cities, city branding, city marketing, creative class, city festivals, urban entrepreneurship.

\section{Introduction}

This study aims to investigate how Istanbul is articulated in terms of neoliberal globalisation through cultural events. Of special significance is the emphasis to be placed on this fact recurring once again, as it is in several cities in the U.S. and Europe, and in a diversified context in Istanbul. While urban culture is determined as the major marketing instrument to make the city a point of attraction, urban place is commodified via urban culture marketing. Economic Impact Analysis published by IFCA (Istanbul Foundation for Culture and Arts), aims to measure the economic impacts of the events organised by IFCA in 2011. The arguments of the study will tested through the discourse of the analysis mentioned. One of the arguments of this study is that there exists a direct nexus between Istanbul becoming another global station of capital flows, and that the middle-class choosing this city as "a city to live". Given that one of the criteria for a city to be "a city to live" for the middle-class is the cultural life in the city; mega cultural events in Istanbul are also essential. This phenomenon is fed by the concepts (or rhetoric) such as "creative cities", "creative classes", "creative industries".

Neoliberalism and globalisation, with their variety of impacts worldwide, have been among the most debated and investigated phenomena in social sciences for the last few decades. These two concepts which have many intersecting aspects should also be the starting point of any study which claims to comprehend today's cities and their transformation. While doing so, instead of transferring and repeating the various definitions made for neoliberalism and globalisation, a short description will be presented and their impacts on cities and Istanbul is going to be discussed.

According to Bauman, it is difficult to make a precise definition of globalisation; instead, we should focus on its social impacts (Bauman, 1998). He has stated that 
what is meant by globalisation is "uncomfortable perception of 'things getting out of the hand" " (Bauman, 1998: 69). This "uncomfortable perception" is actually related to the system behind profit maximisation. Bauman continues:

"In order to elbow their way through the dense and dark, straggly, 'deregulated' thicket of global competitiveness and into the limelight of public attention -goods, services and signals must arouse desire, and in order to do so they must seduce their prospective consumers and out-seduce their competitors. But once they have done it they must make room, and quickly, for other objects of desire, less the global chase of profit and ever greater profit (rebaptized as 'economic growth') shall grind to a halt." (Bauman, 1998: 78).

Harvey defines neoliberalism as "deregulation, privatization, and withdrawal of the state from many areas of social provision have been all too common. Neoliberalism has, in short, become hegemonic as a mode of discourse" (Harvey, 2005: 2). According to Harvey, in this context state shall not make any law limiting the entrepreneurial freedoms and avoid intervening the mechanisms of the free market. Harvey argues that neoliberalism relies on the idea that frequency of market transactions will maximise the social good, thanks to technologies of information, decisions will be made globally and all human actions will be bring into the domain of the global market (Harvey, 2005: 3).

The impact of the neoliberal realm and globalisation on cities is one of the important titles to be examined given these variables. A quick glance at urban history reveals that cities have gone through changes parallel to the changes in production forms. While cities have developed through trade in the medieval they have become the centre of industrial production as capitalism has taken effect. However, as the "cities of industrial production" decrease in number, the "cities of services/technology/finance" are increasing today. This progress has carved out the fate of these cities, of other cities they are in relation with, and of that region in chain reaction. 
On the other hand, the crisis of capitalism (Harvey, 1990) has become apparent in cities as well. Thus, cities began to need new ways to survive. As globalisation demolished the barriers against capital flows, both deindustrialised cities and cities as places where the crisis of capitalism could be clearly and directly observed, have begun to become the stages for a number of developments. Neoliberal realm is using the city in various ways; it is transforming the city. It would not be too much to say that understanding what is happening in cities, where half of the world's population is living (http://news.bbc.co.uk/2/hi/science/nature/4561183.stm) is an important element of understanding what is happening in society and in the world as a whole in the light of all these taking place.

The agglomeration in metropolis measured by millions today has appeared in the 19th century, and absolutely more intensely compared to previous periods in history. There was not any city in Europe in the year 1800 with a population over 1.000.000. However, within a century, population has doubled. As transportation eases and capital intensifies, there were 27 cities with a population over 1.000 .000 by the year 1900 (Mumford, 1989: 529). These quantitative changes which can be grouped into the scale changes related to the population density have also brought about some qualitative reflections (Mumford, 1989). Lefebvre (2003) states that the society is urbanised as a whole now and the concept of urban society can be used to describe this situation. According to Lefebvre, urban society has appeared as a consequence of industrialisation. In order to define the society, it is essential to take into consideration the production relations and the spatial conceptualisation they generate. Cities are centres where economic power is cumulated. An economic model based on agricultural production is not valid anymore; as Lefebvre states, no society other than underdeveloped economies can be characterised as an agricultural society, under the influence of globalisation today.

Mumford (1989) has stated that, with the changes in production forms, urban life goes on in a way how it was in the Neolithic age, but it has begun to change from as of this moment. In parallel with the urban society definition of Lefebvre, Mumford has also stated that all habitat units are formed within the economic rationale of the 
city and that even the axes that the tribes living in the jungle use are produced in the cities. Continuous technological inventions make the pressure on the economic forms heavier, "... power, speed, quantity, and novelty became ends in themselves and no effective attempt was made to control power and quantity with respect to other human needs than expanding production and consumption. Thus, the great metropolises brought into one vast complex the industrial town, the commercial town, and the royal and aristocratic town, each stimulating and extending its influence over the other" (Mumford, 1989: 531).

A competition has begun in the cities after this stage. Mumford continues:

"To have the biggest museum, the biggest university, the biggest hospital, the biggest department store, the biggest hospital, the biggest department store, the urban requirement: and to produce the maximum number of inventions, the maximum number of scientific papers, the maximum number of books became as much as mark of metropolitan success as the maximum number of tons of pig-iron in Pittsburgh or Essen. In short, every successful institution of the metropolis repeats in its own organization the aimless giantism of the whole" (Mumford, 1989: 531).

Bauman (1998) ascertains how the struggles over place evolve through globalisation. While doing this, his analysis is established in the "space wars" framework. The concept is expressed as an increase in demand. Globalisation is one of the prominent phonemona in order to comprehend the transformations of cities. The nexus of the space wars in the contemprary cities is formed by accumulation of capital under the influence of globalisation. The districts where proleteria live, ghettoised centres where ethnic/cultural/political minorities live, neighbourhoods where trafficking takes place have become the places where the new capital has been investing. The underlying reason behind this interest in such neighbourhoods is the rapid capital flow and relevantly increased labour mobility. Mobility of capital and labor has been the dynamic of the urban transformation observed in the last decades. 
This new economic and social restructuring has brought about a new urbanisation and urban governance. Under such circumstances, segragation, exclusion and space wars are the consequences that have emerged in the cities (Hansen, 2006).

Increased mobility of global capital since the 1970s, transformation of production into flexible forms and methods, services sector outpacing the manufacturing sector all comprise the turning point of neoliberalism (Harvey, 1990). In other words, the mode of production has evolved from Fordism to post-Fordism, transforming the face of the cities concomitantly. This transformation which has occured in the 1970s in the United States and in the 1980s in Europe, generated labels such as "world city", "global city" (Sassen, 2001).

\section{Branding the Cities, Blending the Culture and Art}

The persistence of economic development and consumption is trying to be achieved via cities, which turns the city itself into a commodity. While marketing and public relations experts work hand in hand with local governments to look for ways to "market" the city, academia develop theoretical frameworks that feed these approaches. A strong belief that the cities can be marketed and "cooperation" have been diffusing extensively. "Branding" is the major strategy of marketing the urban place and the culture.

Starting from mid 1980s, cultural policies have been perceived in Europe, as a medium which regenerates the urban economy and the physical texture of the city instead of being a mechanism that contributes to social development and a tool that supports social participation. This shift has started the "urban marketing era". From 1990s, this marketing strategy has been replaced with a more integrated marketing form, and the city is "branded" in a wider spectrum of events of entertainment, art and business (Garcia, 2004: 316). Although cities always outshine with their specific characteristics starting from the 19th century, the "competition" between cities has accelarated with globalisation. The PR activities which were run almost superfically until the 1980s, became more integrated with the 1990s (Kavaratzis and Ashworth, 
2005: 507). According to a study on city branding, (Kavaratsiz and Asworth, 2005) branding is defining the urban place so as certain segments of the society can perceive it.

A common "marketing" approach is rooted that geographic areas can be branded as other commodities; however, when a place is branded, its brand is fixed under its real name. According to this approach, the return of branding a city is making the location of the city, its specific characteristic recall and the "useful institutions" for its branding strategy goals, publicly known.

Florida (2002) asserts that the place has become a kind of regulator of the daily life and with this characteristic it has taken over some of the tasks which firms had been doing before. According to this claim, since firms are profit maximising units, cities are needed a similar structuring too. Then anything that causes a minus at the end of the balance sheets should be avoided.

According to Hankinson (2005) who presents suggestions for city branding and city marketing, creating the image of the city is much more complicated than creating the image of a commodity. A city has a variety of faces, from a monolithic entity which reflects a unique image, to a series of services and characteristics which reflect others. Thus, a city as a whole can come into prominence with a completely different image in comparison to a shopping mall. In PriceWaterhouseCoopers' report entitled Cities of the Future (2005) it is stated that the "marketable" characteristics of the city are complicated, these characteristics should be taken into account together and should be used to provide useful relations to the "shareholders" in order to create a strong city brand. Hankinson (2005) states that the complexivity of the city is constituted by different experiences gained as faced by different elements in the city by different consumers and thus the city government cannot control the commodity experience as a whole. 
Brand experts believe that city branding is a long term incestment. It is accepted that the investment should not be made solely in the physical architecture of the city. Recreating the image of the city needs more than that. On the other hand, the image to be created should not contradict the existing image of the city; otherwise it will not be successful. Therefore, it is possible to create a successful city image and brand by ascertaining the existing characteristics of the city and understanding them correctly (Rainsito, 2003).

The city image concept is actually rather slippery. If the image of a place is not packaged and governed by an alliance of professionals who are occupied with marketing the place, it can be decoded differently by different people. That is why Kotler (1993) suggests that during the city branding, a simple and convincing communication process should be followed and that the city image should be constructed on authentic elements which would diversify the city. In this process, even the natural geographic conditions of the place are not disadvantages anymore.

It can be claimed that city branding is a project performed by a coalition consisting of municipal administrators, governors, consciousness industry professionals and business people. The major expectation in branding and offering a city to the global markets is to derive more investments and increase the volume of trade of the city. The competition among the cities in terms of attracting more investments can be seen as the natural consequence of the capitalist place economy (Paddison, 1993).

\section{Festivals as the Tool of Urban Policies}

Stevenson (2003) states that aside from the fact that the cities are the highest populated areas, they are the mostly visited places. Accordingly, density of the movements cause severe changes both in urban texture and in the events organised in the city. Urban places and events that are organised to meet the "tourist gaze" (Urry, 2000), and switch the urban spaces and urban identity into an object for the tourist gaze itself. According to Stevenson (2003), in deindustrialised, post-Fordist cities, a marketing effort can be observed that is arranged with the cooperation of 
municipal administrators and business people with the aim of articulating to the "global world".

This project which can be named as selling the city, materialises the meanings, values and perceptions and markets them by creating a city image. What is being marketed is not just the physical place, all symbolic values and images behind the physical are transformed into monetary values. All this materialising process does not solely aim to affect and attract international investors, visitors and tourists, but also to attract the inhabitants. By including the media within the city marketing process, images related to the city are produced, existing images are reproduced and put into circulation through strategies planned with detail. By doing so, a unique city image and myth is created with regard a place where everybody will wish to live, work or visit.

Zukin develops (1995) the symbolic economy concept, to explain the establishment and the existence of modern capitalist cities, cultural programmes organised in the cities and urban change. Symbolic economy is the business of selling a city image nationally or internationally. Urban public space is conceived and assigned functions within the rationale of this system. While cities are being established, planned and developed, what are going to be included, what are going to be excluded, what are going to be visible and invisible are all taken into consideration. The urban entrepreneur is one of the major actors of the symbolic economy in the city defined with this cultural determinism. Advocates of the symbolic economy together with the businessmen, attempt to create a city at world standards by discriminating their philantropy, pride of the city dweller and identities. "Culture is intertwined with capital and identity in the city's production system" (Zukin, 1995: 12). 
Within the rationale of the symbolic economy, each intervention with the place requires the reproduction of its visual representation, which in return raises the problem of which is going to be used during this representation process. A public culture is needed for this. However, the owners of the urban space are the ones who are taking all critical decisions such as security issues, cultural identity, social organisation and geographical structuring (Zukin, 1995: 24).

\section{A Neo-Liberal Discourse: Creative Cities-Creative Classes}

Cities are situated as the engine of economic development in the whole economic structure. City branding and the orientation of urban investments to support the branding strategy appear as the new urban policy followed to create the attractive destination for capital flows. "Creative class" and "creative city" concepts provide the practical conceptual and rhetorical framework for the advocates of this systematic. Florida (2005) claims that this "creative class" can possess a leading position in this global competition and that this competition will take place on a "creative" ground. Cities provide an open, modest and mobile environment for the creative classes. Investments increase, new job opportunites are generated and economic development is achieved thanks to the creative class.

Florida (2002) also claims that the mainstream urban and development models accepted by the economists and geographists are not sufficient to explain today's cities and regions. According to Florida, closeness to raw materials, availability of transportation means and tax exemptions are not attractive enough for the business world anymore. This approach claims that a new understanding is needed for urban life and constitutes a rhetoric. "Creative people" are the boosters of regional economic development. Economic development could only be possible places where highly educated people live. But there are several reasons for those highly educated people to choose a city to live in. The fundemantal rationale of such a choice is that these cities are "innovative", "diverse", "tolerant" places. 
Florida (2005) argues that each and every individual carries a potential of "creativity" and every person is a natural member of the "creative class". What are the distinctive components of "creative class"? The prominent chacteristic is to be recruited in "creating new significant forms". The creative class divides in two section within itself. "Upper creative class" who are in the nexus of creative class and "creative professionals" who aggregated around the nexus. The creative nexus is composed of scientists, engineers, literati, leisure industry professionals, actors, designers, architects, and people from several professional backgrounds labelled by Florida as "thought leaders" of the modern society who are authors, editors, researches are recruited by think tanks etc.

While the creative nexus creates new forms and designs, the other segment "creative professionals" are employed in high-tech industries, financial services, jurisprudence and health sector. Generally creative professional takes role in the positions to produce solutions for the system and designs built up by the creative class. It is possible to assert these descriptions have emerged as the rhetoric of economic and social transformation in post industrial cities in a discriminate way. Numerous studies indicating the transformation in the cities evolving from industrial economy in to service industry have been carried out.

According to Florida technology, talent and tolerance appears as the dominant criteria and the main motivations of the creative class' choices. These three criteria are necessary in the rooting of the creative class. Tolerance means the notions of open society, to be accepted as a part of the society, the opportunity for expressing the self in terms of ethnic/racial identity and lifestyle. Talent means having a degree at least at undergraduate level. Technology is the concentration of the "innovations" and high-tech in the region. Florida turns all these factors into an index, numbering sexual tendencies, life style preferences and ethnicity in order to understand the locational preferences of creative classes. As a result, Florida finds that the lowest "human capital" belongs to places where the working class live and derives conclusions for the city towards ways for development. 
Although Florida's statements claim to be global, they are criticised that they need to be questioned for different geographies; moreover, that they legitimize the gentrification in the physical appearance and the organic life of the city. It is found out that the indexes of Florida are not verified in other studies (Shaw and Evans, 2006: 11).

Rhetoric of creative cities is considered as a new tool of city marketing strategies that have taken shape with parallel to competition among cities aim to attract more investments. Nevertheless, it is typically observed that each and every city engages in efforts for an image creating process and characterises itself as distintictive city. At this point, the functionality of image creation has to be questioned. Meanwhile, the competition in the name of attracting more investments turns in to a marketing competition as well. The fact triggers the imitation process between cities and it doesn't represent the point of truth, but the power and dominancy of the advocates of such an approach (Hansen, 75).

\section{Marketing Istanbul Via Culture/Art}

In many cities of the world, cultural events are gradually percieved as the tool of physical, economic, cultural and social urban transformation. Since 1980s, it has been observed that municipal administrators are have been concentrating on urban space planning principles that lead the way for making more it convenient for masses to access cultural resources, and this is accepted as the indicator of successful urban development. It is strongly believed that the cultural policies and mega cultural events perform a key function against social, economic and political problems in the cities.

A quick glance at mega cultural/art events organised in Istanbul, shows that the city is along the same axis with the western cities. Increasing number of culture/art events have a function and meaning beyond sharing international experience. In this context, in a study conducted by Yardimci (2005) the relationship between culture/art events and the city, the changes that the city faced, and how the actors of 
the events percieved this process are shown comprehensively. Data show that Istanbul is one of the deindustrialised cities, and among other strategies culture/art events are one the strategies fort the city to survive.

Table 1. Sectoral Distribution of Employement in Istanbul

\begin{tabular}{|l|l|l|l|}
\hline Year & Agriculture (\%) & Industry (\%) & Services (\%) \\
\hline $\mathbf{2 0 0 4}$ & 0.8 & 42.0 & 56.7 \\
\hline $\mathbf{2 0 0 5}$ & 0.7 & 43.0 & 56.4 \\
\hline $\mathbf{2 0 1 0}$ & 0.4 & 40.0 & 59.6 \\
\hline $\mathbf{2 0 1 1}$ & 0.5 & 39.8 & 59.7 \\
\hline $\mathbf{2 0 1 2}$ & 0.6 & 36.7 & 62.7 \\
\hline $\mathbf{2 0 1 3}$ & 0.6 & 35.1 & 64.3 \\
\hline
\end{tabular}

Derived by the author from several statistics issued by the Turkish Statistical Institute (TSI).

Note: The construction sector is defined as a component of the industrial sector by TSI.

An analysis published by IFCA will form the data for this study, and the arguments above will be tested by referring to the report's rhetoric and discourses. The analysis, namely IFCA Economic Impact Analysis, aims to measure the economic impacts of the events organised by IFCA in 2011. The report gives information on the aims of IFCA and the events organised, the number of visitors, the ticket expenditure for per visitor, demographic profile of visitors, financial support provided by the state to the culture/art events, and finally evaluates and predicts the contribution of these events to urban and country economy.

The report, consistently with its name, emphasises that in more than 400.000 visitors and approximetly 10.000 foreign visitors visited the events orginesd by IFCA in 2011. Furthermore, in the areas where these events took place 17,3 million TL (7,5 million $€$ ) was spent excluding ticket fees (IFCA, 8). Numerical statistics are given, it has been said that "the impact of these events have more impact on brand value of Istanbul, 
publicity of Turkey, tourism, employment of qualified labor, increasing of the quality of city life, than its direct economic contribution" (IFCA, 10).

Regarding on the statistics, the length of stay in Istanbul and the expenditures of foreign visitors are also shown by the report with the comparisons with other cities in the world. As a result, it has been noted that the overall expenditures are low. In some part of the analysis it is overtly expressed, and implied in other parts that culture and art could be used as a marketing strategy. According to the analysis "As well as preserving cultural heritage, it is crucial that to give importance to provide art events of good quality, in order to making Istanbul a point of attraction for culture tourism and encourage foreign visitors to visit the city again and extend their lenght stay" (IFCA, 10).

In this context, the impact analysis of 2010 European Capital of Culture, another project of city marketing, was referred to and it harbingers with pleasure that through the 2010 European Capital of Culture events, the length of stay and expenditures rose. That data is used to support the necessity of "cultural heritage and art events for cultural tourism" arguement. Related with that fact, during the Istanbul Bienalle, which is one of the major events organised by IFCA, it is claimed that the occupancy rate during the Bienalle is increased $5-10 \%$. Leaning to this numbers, the authors of the analysis believe that because the duration of the events organised by IFCA is half-year long, this can be a chance to raise the revenues. 
Table 2. Festivals organised by IFCA between 2010-2014.

\begin{tabular}{|c|c|}
\hline FESTIVAL & DATE \\
\hline & 2010 \\
\hline 17. International Istanbul Theater Festival & 10 May-10 June 2010 \\
\hline 29. Istanbul Film Festival & 3 -18 April 2010 \\
\hline 38. International Istanbul Music Festival & 3-30 June 2010 \\
\hline \multirow[t]{2}{*}{ 17. Internatıonal Istanbul Jazz Festival } & 1-15 July 2010 \\
\hline & 2011 \\
\hline 30. Istanbul Film Festival & 2 -17 April 2011 \\
\hline 39. International İstanbul Music Festival & 4-29 June 2011 \\
\hline 18. Internatıonal Istanbul Jazz Festival & 1-19 July 2011 \\
\hline \multirow[t]{2}{*}{ 12. Istanbul Biennial } & $\begin{array}{l}17 \text { September - } 13 \text { November } \\
2011\end{array}$ \\
\hline & 2012 \\
\hline 18. International Istanbul Theater Festival & 10 May-5 June 2012 \\
\hline 40. Istanbul Music Festival & 31 May-29 June 2012 \\
\hline 31. Istanbul Film Festival & 31 March -15 April 2012 \\
\hline Istanbul Design Biennial & 13 October-12 December 2012 \\
\hline \multirow[t]{2}{*}{ 19. Istanbul Jazz Festıval } & 3-19 July 2012 \\
\hline & 2013 \\
\hline 32. Istanbul Film Festival & 30 March-14April 2013 \\
\hline 41. İstanbul Music Festival & 4-29 June 2013 \\
\hline 20. Istanbul Jazz Festival & 2-18 July 2013 \\
\hline \multirow[t]{2}{*}{ 13. Istanbul Biennial } & 14 September-20 October 2013 \\
\hline & 2014 \\
\hline
\end{tabular}




\begin{tabular}{|l|l|}
\hline 33. Istanbul Film Festival & 5-20 April 2014 \\
\hline 19. International Theater Festival & 9 May-5 June 2014 \\
\hline 42. Istanbul Music Festival & 1-27 June 2014 \\
\hline 21. Istanbul Jazz Festival & 1-16 July 2014 \\
\hline
\end{tabular}

Derived by the author from IFCA website at www.iksv.org

Aside from the ticket fees, accomodation and transportation, another data that included within the analysis suggest the economic impact should be considered. Referring to the number of visitors, which is 403.60 , in the events organised by IFCA during 2011, the total expenditure is 14.5 million TL (6.1million $€$ ) was promising figure to reach the desired amount (IFCA, 32). Reviewing all the events organised by IFCA, with the effet multiplicateur the economic growth of 70 million TL (29.3 million $€)$ is praised.

All these evaluations, comparisons and explanations are the keystones of the road lengthen from the point of departure. The departure is, as emphasised the epilogue of the analysis, that heralding cultural events will promote the "brand value" of Istanbul. Here of it is emphasised that cultural/art events are the vital mechanisms of city branding, especially branding of Istanbul, it is demanded the necessary elements need for to empowering the pillar with the ground:

If the share of IFCA from Promotion Fund of the Prime Ministry is increased, this would be an appropriate decision related to the the fund's goals. From this point of view "the public should consistenly support trasferring the cultural prosperity into economic value in the field of culture and art" (IFCA, 42).

The realm of conception that insists on transforming the culture into economic values and embraces the city marketing as a strategy is the excellent reflection of the term "urban entrepreneurship" used by David Harvey (2001). It is definite that "the price" of the commodity with a shiny package would be higher, so for the branded 
city, too. It is necessary to share the rent that comes out of the increased price. It is clear that the sharing would not be equal and fair. The process of city branding and putting a city before others with diversed chracteristics can be described as pushing the unwelcome to the backstage (Goffman, 1973), it can be predicted the slices for the ones at the backstage won't be so big. Findings of the numerous studies focusing on the city branding from a critical point of view, gentrification and segregation are the shares of the of the ones at the backstage. A glance at the actors of the process of gathering economic value via city and culture, the term of "urban entrepreneurship" gains a more explicit meaning.

According to Harvey urban entrepreneurship refers to the coalition which consists of state apparatus (local, metropolitan, regional, national and supranational) civil organisations (chambers of commerce, educational institutions, research institutions, NGOs etc.) and private initiatives (firms and individuals) which aim to support urban development and administration. Such urban policies are relevant to neoliberal globalisation. Harvey states that the liquidised capital does not always flow through the search for inexpensive labor. Thus, capitalism has gained a geographic facet. Gathering rent via urban space is a consequence of such a change. If the arguements such as "uniqueness", "authenticity", "specifity" are taken as the intrumental elements of monopolist rent, cultural products, cultural praxis, physical texture of the city are the solid ground for collecting monopolist rent. Within this mechanism, being a city with the claim of "uniqueness" means just to serve to the monopolist rent. The cities which are in contrast with the spaces defined as world cities or global cities, are getting involved in a competition of diversification. In this process, the "transformation" of cities brings up several cultural and social problems. Emphasise on local culture is inadequate in answering the questions "whose culture?" and "which culture?" and in providing fair and balanced cultural representation. Only a few will benefit from the profit. While unwelcomed cultural, social and political elements would be swept away, the city turns in to a secure and open place for tourists, middle class urban dwellers and entrepreneurs (Harvey, 2001). So the city branding would be accomplished. 
While Istanbul is described and branded via culture, it becomes a "global city", "world city", "financial center". Such a change is also desired by ACMIIT (The Association of Capital Market Intermediary Institutions of Turkey) which has very different goals and organisational structure. In the introduction of the report published by the Association titled as Global Financial Centers and Istanbul, it is stated that it is time for Istanbul to become a financial center leaning to political, economic and legal background. It is stated that: “The project of Istanbul's designation as 2010 European Capital of Culture will strongly contribute to this process. If other circumstances are fulfilled it won't be a dream for Istanbul to become a financial center" (ACMIIT, i). On the other hand academia should play its role, support the process of economic harvest of culture the and the branded city project. In the manifestation of Branded Cities Masters Programme, which is conducted with the co-operation of a private university which is founded in Istanbul and Culture City Foundation, it is stated that "because of opened for future of Brand Cities (...) outlines own vision that the contribution of Brand Cities to improve the country's economy with new philosophies, systems and strategies to produce own values."http://www.kulturkentivakfi.com/projects/detail.aspx?SectionID=NUJdUZ cQUTZ6iTkMCcvUDQ\%3d\%3d\&ContentID=TuR10ymn1Us\%2b2cn\%2fF0fYow \%3d $\% 3 d$

Urban entrepreneurs who redescribe the city, are generally from diversed fields and do not have direct and organic relations with each other. As Adorno states:

"Whoever speaks of culture speaks about administration as well, whether this is his intention or not. The combination of so many things lacking a common denominator-such as philosophy and religion, science and art, forms of conduct and mores - and finally the inclusion of the objective spirit of an age in the single word "culture" betrays from the outset the administrative view, the task of which, looking down from on high, is to assemble, distribute, evaluate and organize." (Adorno, 1991: 107). 
As Adorno vigorously expressed, several elements get knotted at a common denominator where they resemble, and this resemblence may be defined as profit. While collecting, mixing, synchronising, culture is the magic word and the cement for this process, and it is quite mythic in nature. The general acceptence is that whenever culture is spoken of, there should not be any negative connotation related to it. Relying on this mythic character, administrative view always blurs the uneven denomination of the denominator. While speaking of culture, some may maximise the numerator in the fraction.

\section{Concluding Remarks}

It can be observed that the impact of neoliberal economy is strengthining by breaking the spatial countours and utilising the cultural field. In this context, culture and art are degraded as tools of marketing. Capitalist, municipal administrators, think tanks, NGOs, organisations in the field of art and culture, and academy are the structural elements of the alliance block, which are from different fields, but have implicit/explicit concurrence and cooperation. Such a comprehension and strategy which turns into an interference with urban space and culture, stimulates the urban inequality and segregation.

The rationale of capitalist economic growth, development and progression depends on continous production and profit maximisation. Such a realisation, which is irrational, also has impacts on urban place and culture. The premise of the irrational dimension is that it is unsustainable, therefore, it is everlasting impossible growth. It can be claimed that this unsustainable situation is valid in the urban context.

Organising cultural/art events has long been observed as an urban marketing strategy of strengthening the economy by deindustrialised cities. In the case of Istanbul, it can be claimed that the city's economy rests upon sources other than the industrial sector. Imposition of neoliberal policies on one hand and the aim of delaying / preventing / overcoming the systemic crisis on the other hand, have always been the top of the political realm's agenda, with an intentional choice of an 
deindustrialised city. By this way, the expression of short term and inequal economic growth through figures becoming an element of rhetoric can be materialised. Eventually, while the city turns to the basin of the rent, for estate speculators and developers, the existing economic, social, political and cultural inequalities become a deadlock. The idea of strengthening the urban economy through culture/art events overlaps the neo-liberal policies and the dominant political rationality.

In June 2013, the social resistance which emerged in Istanbul and spread throughout the country, reminds Bauman's space wars. The uprising turned the urban space into a space of struggle and demonstrated the denial of neoliberalism, defining the urban space and culture as the servants of capital. 


\section{REFERENCES}

Adorno, Theodor W. (1991). The Culture Industry: Selected Essays on Mass Culture. London; New York: Routledge.

Balsas, Carlos. J. L. (2004). City Centre Regeneration in the Context of the 2001 European Captial of Culture in Porto, Portugal. Local Economy. No. 4, pp. 396-410

Bassett, K. (1993). Urbanal Cultural Strategies and Urban Regeneration: A Case Study and Critique. Enviroment \& Planning, pp. 1773-1789.

Bauman, Zygmunt (1998). Globalization: The Human Consequences, New York: Columbia University Press.

Bianchini, Franco, Ghilardi, Lia (2007). Thinking Culturally About Place. Think Piece in: Place Branding and Public Diplomacy. Palgrave Journals.

Burd, Gene (2008). The Mediated Metropolis as Medium and Message. International Communication Gazette, 70:95, pp. 209-222.

Cox, K. ve Wood Andrew (1994). Local Government and Local Economic Development in the United States. Regional Studies 28, pp. 640 - 645.

Evans, Graeme (2005). Measure for Measure: Evaluating the Evidence of Culture's Contribution to Regeneration. Urban Studies, Vol. 42, Nos. 5/6, pp. 959-983.

Florida, Richard L. (2005). Cities and Creative Class. New York: Routledge.

Florida, Richard L. (2002). The Rise of the Creative Class: and How It's Transforming Work, Leisure, Community and Everyday Life. New York: Basic Books.

Garcia, Beatrice (2004). "Cultural Policy and Urban Regeneration in Western European Cities: Lessons from Experience, Prospects for the Future". Local Economy, Vol. 19, No. 4, 312-326. 
Goffman, Erving (1973). The Presantation of Self in Everyday Life. New York: Overlook Press.

Hankinson, Graham (2005). “Destination Brand Images: A Business Tourism Perspective". Journal of Services Marketing, 19/1, 24-32.

Harvey, David (2005). A Brief History of Neoliberalism. Oxford University Press: New York.

Harvey, David (1990). The Condition of Postmodernity. Oxford: Blackwell Publishing.

Harvey, David (2001). Spaces of Capital Towards a Critical Geography. New York: Routledge.

Hansen, Anders Lund (2006). Space Wars and the New Urban Imperialism. Lund: Lund University, Sweden.

Kavaratzis, Mihalis and G. J. Ashworth (2005). “City Branding: An Effective Assertion of Identity or a Transitory Marketing Trick?". Tijdschrift voor Economische en Sociale Geografie, Vol. 96, No. 5, 506-514.

Kotler, Philip., Haider, Donald H. Haider and Rein Irving (1993). Marketing Places: Attracting Investment, Industry and Tourism to Cities, States and Nations. New York: Simon\&Schuster.

Lefebvre, Henri (2003). The Urban Revolution. R. Bonono (Trans.), Minneapolis: University of Minnesota Press.

MacGuigan, Jim (2005). Neoliberalism, Culture and Policy. International Journal of Cultural Policy, Vol. 11, No. 3, ss. 506-514.

Mumford, Lewis (1989). The City in History-Its Origins, Its Transformations, and Its Prospects, San Diego, New York, London: Harcourt. 
Paddison, Ronan (1993). City Marketing, Image Reconstruction and Urban Regeneration. Urban Studies, Vol. 30, No. 2, ss. 339-350

Rainsito, Seppo (2003). Success Factors of Place Marketing: A Study of Place Marketing Practices in Northern Europe and the United States. Helsinki: Helsinki University of Technology.

Shaw, Phyllida. and Evans, Graeme (2006). Arts and Culture in Regeneration. The International Federation of Arts Councils and Culture Agencies.

Sassen, Saskia (2001). The Global City: New York, London, Tokyo. Princeton: Princeton University Press.

Stevenson, Deborah (2003). Cities and Urban Cultures. Philedelphia: Open University Press.

Urry, John (2000). Consuming Places. London; New York: Routledge.

Yardımcı, Sibel (2005). Kentsel Değişim ve Festivalizm: Küreselleşen İstanbul'da Bienal. İstanbul: İletişim Yay.

Zukin, Sharon. (1995). The Cultures of Cities. Oxford: Blackwell.

\section{Internet}

Istanbul Foundation of Culture and Art (2012). IFCA Economic Impact Analysis. http://cdn.iksv.org/media/content/files/IKSV_Ekonomik_Etki_Arastirmasi.pdf accessed 23 June 2013.

PriceWaterhouseCoopers (2005). Cities of the Future. http://www.pwc.com/en_GX/gx/government-public-sector-research/pdf/citiesfinal.pdf accessed 10 January 2014.

The Association of Capital Market Intermediary Institutions of Turkey. 2007. Global Financial Centers and Istanbul. http://www.tspakb.org.tr/tr/Portals/0/57ad7180-c5e7-49f5-b282- 
c6475cdb7ee7/AIM_Yayin_ve_Raporlar_Arastirma_Raporlari_Global_Fin_Mer.pdf accessed 21 November 2013.

Whitehouse , David (2005). "Half of humanity set to go urban" May 19, 2005.

http://news.bbc.co.uk/2/hi/science/nature/4561183.stm accessed April 20, 2014. 